\title{
Anatomical Description of Scapulocoracoid and Gill Arches of Benthobatis kreffti
}

\author{
Ítalo Rafael Bini Junior ${ }^{1 凶}$, Camila Mayumi Hirata dos Santos ${ }^{1,2}$, \\ Otto Bismarck Fazzano Gadig ${ }^{1}$
}

\begin{abstract}
This study describes the scapulocoracoid and the ventral gill arches of a rare benthic elasmobranch, Benthobatis kreffti, based on specimens collected at depth of $500 \mathrm{~m}$ off the coast of São Paulo state, southern Brazil. The scapulocoracoid has an anterior fontanelle that is placed laterally. Condyles are similar in size, unequally spaced, and they are not aligned horizontally. The mesocondyle is located below the other condyles. The posterior fenestrae are allocated within the cartilage of the scapulocoracoid, while the anterior fenestrae cross its lateral-posterior segment. The suprascapula is arched posteriorly, and it is not connected or fused to the synarcual or the vertebral column. Three unfused hypobranchial elements were found in the ventral gill arches. The ceratobranchials are rod-like shaped, with fenestrae from first to fourth ceratobranchials. The fifth is morphologically distinct and connected to the scapulocoracoid. There is a pair of elements above the basibranchial copula, of unknown origin, also reported for other congeneric species, Benthobatis marcida. Such character could represent an autapomorphy of the genus.
\end{abstract}

Keywords: anatomy, skeleton, electric ray, Torpediniformes; Chondrichthyes

Edited by Juan Carlos Salcedo-Reyes 㺼 Andrés Felipe Navia

1. Laboratório de Pesquisa de Elasmobrânquios, Universidade Estadual Paulista "Júlio de Mesquita Filho" Campus Experimental do Litoral Paulista, Praça Infante Dom Henrique, s/n, São Vicente/SP, Brasil

2. Universidade Estadual Paulista "Júlio de Mesquita Filho", Campus de Rio Claro, Avenisa 24A, 1515, Rio Claro/SP, Brasil.

Received: 02-12-2014 Accepted: 08-05-2015

Published on line: 29-05-2015

Citation: Bini IRJ, Santos CMH, Gadig OBF (2015) Anatomical Description of Scapulocoracoid and Gill Arches of Benthobatis kreffti. Universitas Scientiarum 20(3): 305-312 doi: 10.11144/Javeriana.SC20-3.adsg

Funding: Conselho Nacional de Desenvolvimento Científico e Tecnológico - CNPq.

Electronic supplementary material: N/A

\section{Introduction}

The batoid fishes (rays, skates, guitarfishes and sawfishes) represent approximately $54 \%$ (630 in 1170) of all Chondrichthyes species (Aschliman et al. 2012). The numbfishes (Narcinidae, Torpediniformes) consist of four genera and about 18 species of small to medium sized benthic elasmobranchs with electric organs in the disc (McEachran \& Carvalho 2002). The so-called blind electric rays, genus Benthobatis, are known by four deep sea species, and they share the remarkable feature of vestigial and non-functional eyes (Carvalho 1996b). Benthobatis kreffti Rincón, Stehman \& Vooren 2001 is the smallest electric ray species (about $300 \mathrm{~mm}$ total length - TL), it was described based on specimens caught along the southern Brazilian continental slope at depths between 400 and 600 meters (Rincón 1997, Rincón et al. 2001). Due to the scarcity of collected specimens, its biological and natural history data are

\section{cc)(1)(2) (2)}


virtually unknown and most of the information comes from the original description (Rincón et al. 2001).

Any anatomical approach in the study of electric rays is important to elucidate the interrelationships among its representatives, as well as within the general batoid phylogeny, since there is a historical disagreement in the phylogenetic position of Torpediniformes, regarded as a basal lineage (Nishida 1990, McEachran et al. 1996, McEachran \& Aschliman 2004) or derived in relation to Rhinobatiformes (Shirai 1996). Elasmobranch skeletal analysis are a useful tool for taxonomy and systematics studies, remarkably those involving the neurocranium, gill arches, scapulocoracoid, pelvic girdle, clasper, and synarcual (Hubbs et al. 1968, Compagno 1977, McEachran 1983, Miyake \& McEachran 1991). Out of the five characteristics that support Torpediniformes as a group, three of them involve the skeleton (Claeson 2014).

Regarding the genus Benthobatis, there is available information on the neurocranium, hyomandibula, branchial arches, scapulocoracoid, propterygium, synarcual, pelvic girdle and clasper (Carvalho 1999a,
Rincón et al. 2001, Carvalho et al. 2003, Claeson 2014). However, for Benthobatis kreffti there are no descriptive data for the ventral gill arches and the scapulocoracoid, and the present study intends to complement the anatomical information of the species, through the analysis and comparison of these structures.

\section{Materials and Methods}

The analysis was based on 10 adult specimens of Benthobatis kreffti (five $206 \mathrm{~mm}$ to $245 \mathrm{~mm}$ TL males; five $228 \mathrm{~mm}$ to $251 \mathrm{~mm}$ TL females) caught at $500 \mathrm{~m}$ deep bottom trawls during research cruise carried out by the Universidade Estadual Paulista (UNESP) along the São Paulo state coast, southern Brazil, between July 31 to August 2, 2003. The species identification was based on Rincón et al. (2001).

After formalin fixation and alcohol preservation, the specimens had their skin, muscles and connective tissue removed by a dissection procedure, exposing the scapulocoracoid cartilage and gill arches, a stereomicroscope was employed for this process. The
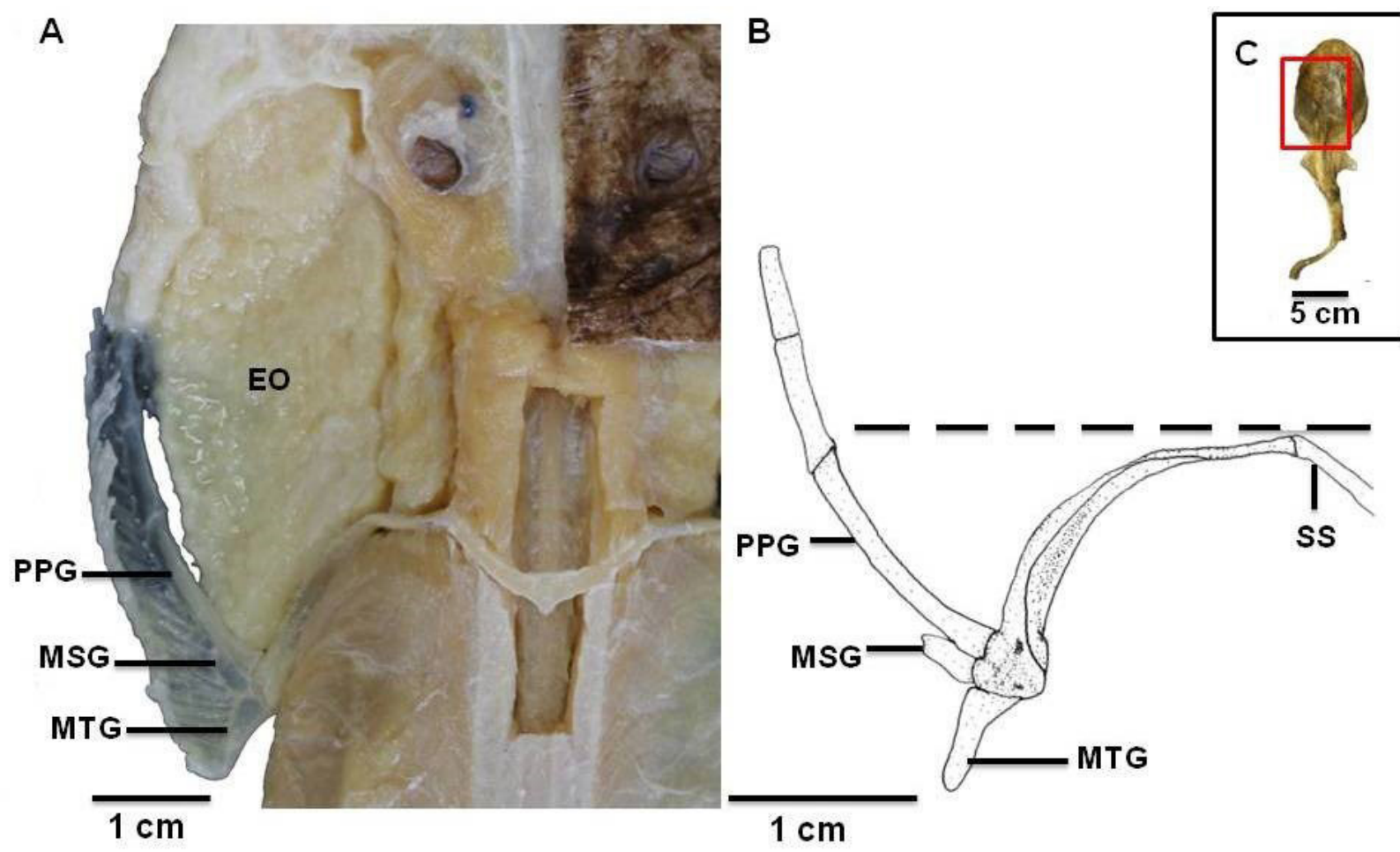

Fig. 1. Dorsal view of the pterygia region of Benthobatis kreffii in A. the plate in B. and an outline of the animal in C. Propterygium (PPG); mesopterygium (MSG); and metapterygium (MTG); electric organ (EO) and the dashed line is the level of suprascapula. 
skeletal terminology follows Miyake \& McEachran (1991) and McEachran et al. (1996).

\section{Results}

Scapulocoracoid: It is the skeletal structure that supports the pectoral fins through the articulation of the condyles with the pterygia. The propterygium (PPG) is tubular and rectilinear in shape, and extends to the level of suprascapula (Figure 1). The mesopterygium (MSG) is flat, rectangular in shape, and shorter than the others, while the metapterygium (MTG) is flat, triangular in shape, and widest in its anterior region (Figure 1). The scapulocoracoid has two bar-like structures, both are arched and have thin and delicate cartilage. The dorsal one, the suprascapula (SS), is posteriorly bowed (Figure 2) and not connected or fused to the synarcual or the vertebral column (Figure 1); the ventral one, the coracoid bar (CB) is anteriorly bowed. The anterior fontanelle (AF) is triangular and laterally positioned (Figure 3). The lateral-posterior segment is extensive and its posterior region has the condyles and fenestrae (Figure 3). The procondyle
(PRC) is anteriorly directed, while the mesocondyle (MSC) is laterally directed and the metacondyle (MTC) is posteriorly directed, the first two are closest to each other and the metacondyle farther away (Figure 3). The condyles are similar in size and are not aligned horizontally, the mesocondyle is positioned lower than the others (Figure 3). The anterior dorsal and ventral fenestrae (ADF and AVF, respectively) pass through the lateral-posterior segment of the scapulocoracoid. The posterior dorsal and ventral fenestrae (PDF and PVF, respectively) are located in a cavity within the cartilage of the posterior scapulocoracoid region (Figure 3).

Ventral gill arches: They are a set of skeletal elements that support the gills, with three unfused hypobranchial elements (HB 1-3), the first of which is half arced in shape and the second and third are approximately triangular in shape (Figure 4). The pseudohyal has a rod-like shape and it is positioned ventrally to the first hypobranchial. The second and the third hypobranchials are close to an element of unknown origin that is found above the basibranchial copula (indicated by the symbol "?" in Figure 4).
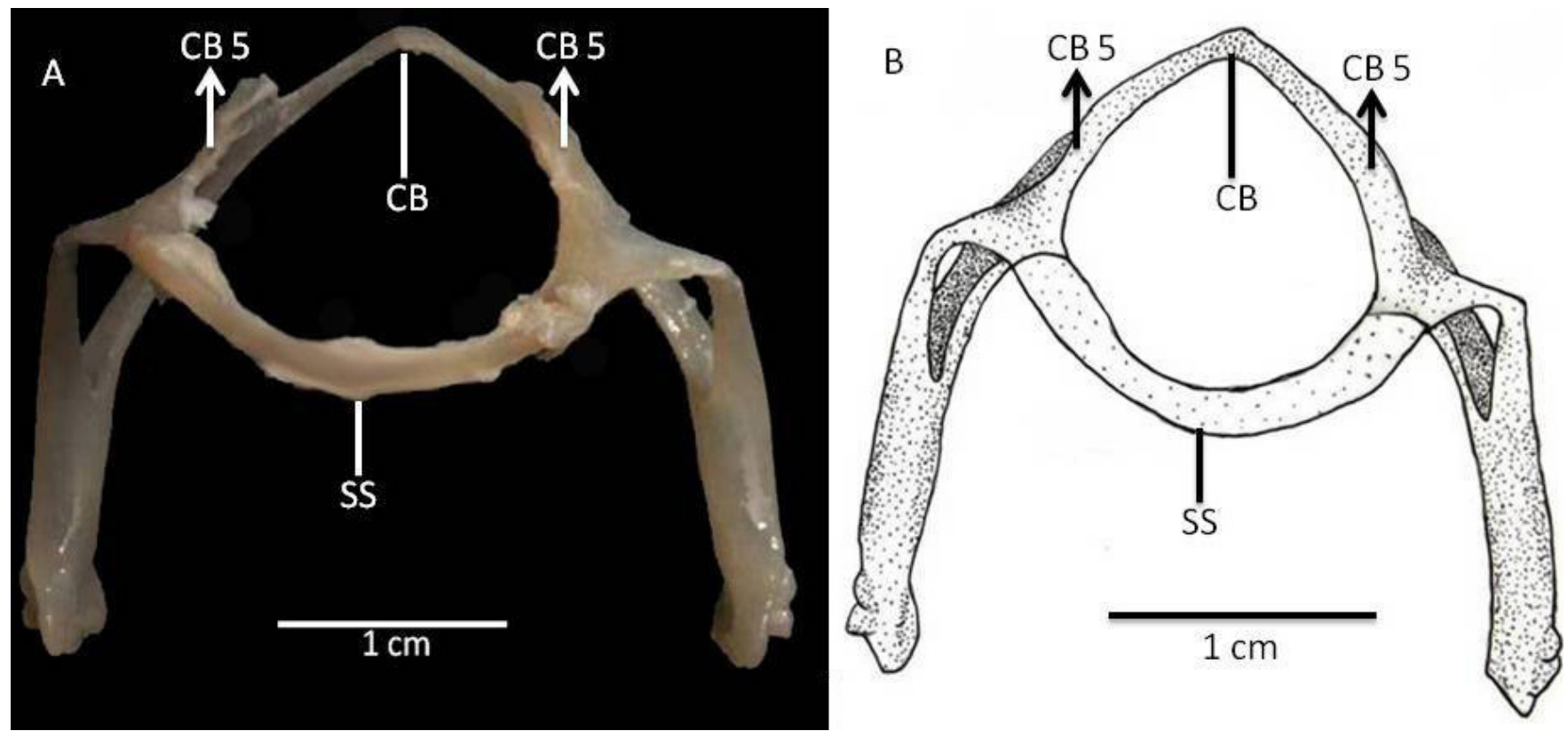

Fig. 2. Dorsal view of the scapulocoracoid of Benthobatis kreffti in A. and the plate in dorsal view in B. Suprascapula (SS); coracoid bar (CB) and arrows indicating where is the articulating with the 5th ceratobranchial (CB5). 
Meanwhile, the ceratobranchial elements (CB 1-5) are rod-like in shape (Figure 4). The species possesses fenestrae until the fourth ceratobranchial, and the fifth ceratobranchial is morphologically distinct. The first three are near to its respective hypobranchial, while the fourth ceratobranchial is close to the middle- bottom portion of the basibranchial copula and it does not make contact with any hypobranchials. The fifth ceratobranchial is located more posteriorly to the basibranchial copula (Figure 4), and it articulates with the anterior region of the scapulocoracoid.
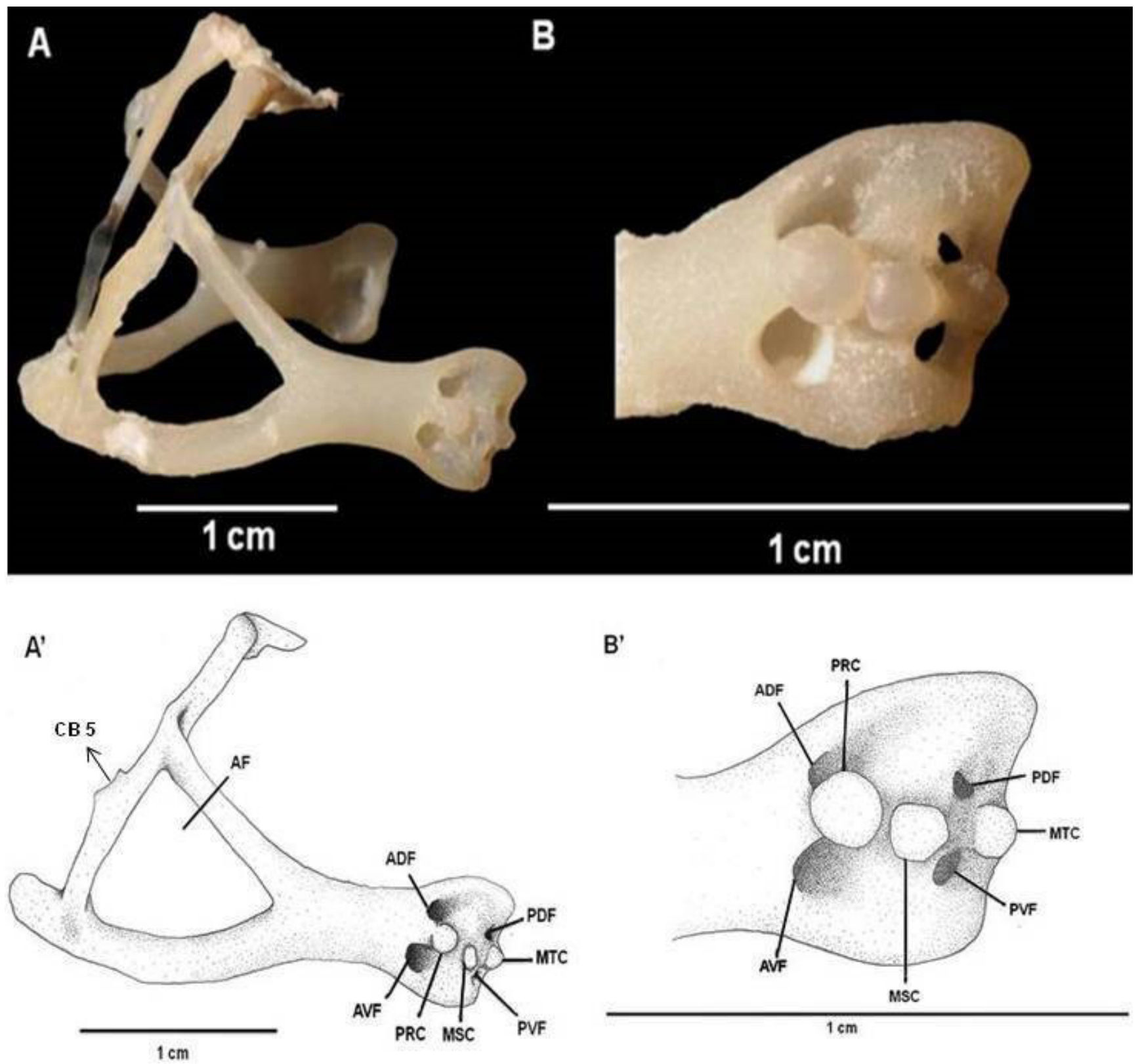

Fig. 3. Left lateral view of the scapulocoracoid of Benthobatis kreffit in A. and in detail of the condyle region in B. Plate in lateral view in A' and a detail of the condyle region in $\mathrm{B}$ ' and arrows indicating where is the articulating with the $5^{\circ}$ ceratobranchial (CB5). Anterior fontanelle (AF); anterior dorsal fenestra (ADF); anterior ventral fenestra (AVF); posterior dorsal fenestra (PDF); posterior ventral fenestra (PVF); procondyle (PRC); mesocondyle (MSC); metacondyle (MTC); Anteior region (An) and Posterior region (Po). 


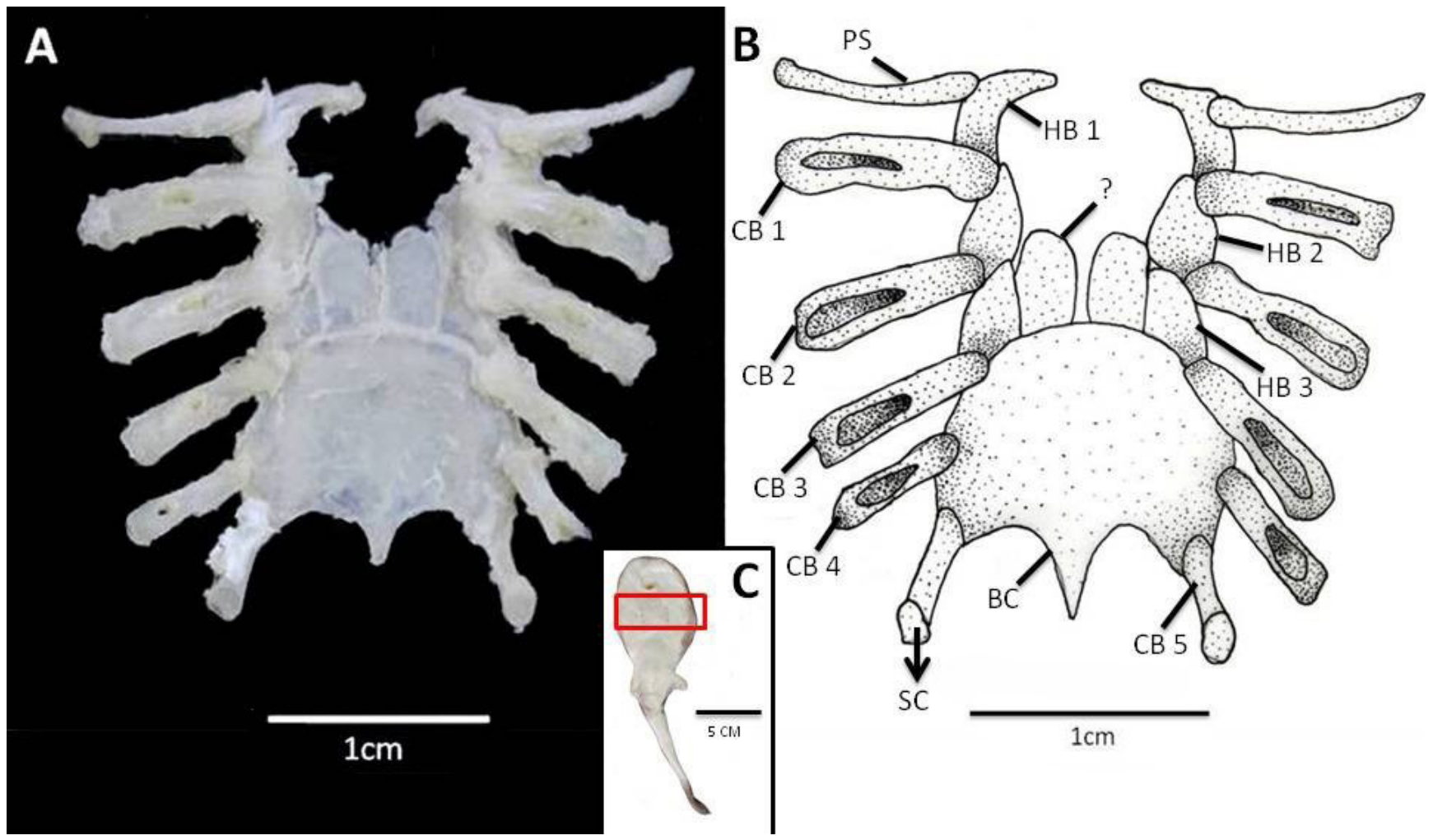

Fig. 4. Ventral view of the gill arches of Benthobatis kefffi in $\mathbf{A}$ and the plate in ventral view in $\mathbf{B}$ and an outline of the animal in $\mathbf{C}$. Hypobranchials 1-3 (HB1-3); ceratobranchials 1-5 (CB 1-5); pseudohyal (PS); basibrachial copula (BC); unkown elements (?) and arrows indicating where is the articulation with the scapulocoracoid (SC).

\section{Discussion}

The propterygium of electric rays is elongated and accommodates the electric organ (Claeson 2014). It extends to the level of the suprascapula in B. kerefti, though in Benthobatis marcida it extends to the posterior region of the anterior fontanelle. The mesopterygium in B. kreffti, B. marcida, Narcine brasiliensis and Diplobatis pictais smaller than the proterygium and metapterygium (Claeson 2014).

Carvalho (1999b) reported that Benthobatis moresbyi has a semi-circular scapulocoracoid arched anteriorly in dorsal view, similar to the anatomy observed here in B. kreffti. Benthobatis kerefti possesses the suprascapula not directly connected to the synarcual or to the vertebral column, the same state reported for Torpediniformes by Heemstra \& Smith (1980). However, in other congeneric species, B. marcida, the suprascapula articulates with the posterior vertebrae of the synarcual (Claeson 2014). In B. kreffti the suprascapula is posteriorly arched, similar to $B$. moresbyi (Carvalho 1999b), while it is straight in B. yangi and B. marcida (Carvalho et al. 2003; Claeson 2014). Concerning this feature in other narcinid genera and species (Discopyge tschudii, Diplobatis picta and N. brasiliensis), the suprascapula is anteriorly bowed, which separates the genus Benthobatis from its closest groups (Claeson 2014).

The arrangement of the three condyles is an important feature of the scapulocoracoid of electric rays. McEachran et al. (1996) reported the condyles are not horizontally arranged in the anterolateral aspect of the scapulocoracoid of Torpediniformes. This non-horizontal configuration is found in Narkidae and Narcine brasiliensis (McEachran et al. 1996), in which the condyles are oriented diagonally, and the procondyle is higher than the others. In B. kreffti, the condyles are not arranged horizontally, but are not 
diagonally organized either, the metacondyle is slightly above the mesocondyle. Carvalho et al. (2002) found a meso-metacondyle fusion in Narcine insolita, unlike $B$. kreffti and Narcine brasiliensis, which have three separate condyles. The horizontal orientation of the condyles is considered apomorphic, and McEachran et al. (1996) report that the condition is similar in Torpediniformes and Pristiophoridae.

In $B$. kereffi, the anterior fenestrae are bigger than the posterior fenestrae, different from the condition found by Nishida (1990) in Narke japonica, whose ventral fenestrae are bigger than the dorsal fenestrae. Changes in the lateral face of the scapulocoracoid may be continuous, which may not be ideal for phylogenetic analysis of species; however in analyses involving higher taxonomic levels, such as families and genera, this character can be useful (Nishida 1990, Shirai 1996, McEachran et al. 1996, McEachran \& Aschliman 2004).

The ventral gill arches of Batoidea have the same skeletal components as those of other Chondrichthyes; however, there are variations in these components (Miyake \& McEachran 1991). The same authors claim that the structure of the hypobranchial elements in electric rays is more varied than in other groups of rays.

Benthobatis kreffti, B. marcida, Discopyge tschudii, Heteronarce mollis, Hypnos subnigrum and Torpedo torpedo have three hypobranchials, however the shape and arrangement of these elements may vary (Claeson 2014). Other genera from the order Torpediniformes have fused hypobranchials, e.g. Narke and Diplobatis, resulting in one or two hypobranchial elements (Miyake \& McEachran 1991).

There is some variation of the fourth ceratobranquial among the Torpediniformes. Benthobatis kreffti, Benthobatis marcida and Discopyge tschudii have this ceratobranquial articulating with the basibranchial copula. However in Torpedo californica, it articulates with the fourth hypobranchial element, and in Diplobatispictus it is close to an element resulting from the fusion of the second, third and fourth hypobranchials (Miyake \& McEachran 1991). Benthobatis kreffti presents fenestrae in the first four ceratobranchials, as in Narke japonica (Nishida 1990), while N. brasiliensis exhibited fenestrae only in the first three ceratobranchials (Carvalho 1999a). The fifth ceratobranchial is morphologically distinct from the others, and it articulates with the anterior region of the scapulocoracoid in B. kreffti, as observed in N. brasiliensis and B. moresbyi (Carvalho 1999 a,b).

The shape of the basibranchial copula of B. kreffti is similar to those of Discopyge tschudii, Diplobatis picta and Benthobatis marcida. B. marcida, however, has the most rounded copula and Diplobatis picta also has a projection in the anterior region (Miyake \& McEachran 1991, Claeson 2014).

There is a pair of elements anterior to the basibranchial copula in B. kreffti, whose origin is unknown. These elements have also been reported in a study on Benthobatis marcida (Miyake \& McEachran 1991), but they were not cited by Claeson (2014). These structures may be an autapomorphy of the genus, though additional anatomical and embryological studies, including other species, are needed to confirm this hypothesis.

\section{Conclusion}

The scapulocoracoid and gill arches are useful for taxonomic or systematic studies, as well as for Torpediniformes phylogenetic analysis. Additional anatomical and embryological studies would be necessary to access more detailed features, in order to elucidate the origin of unknown element of Benthobatis, a virtually unknown deep sea elasmobranchs group.

\section{Acknowledgements}

We would like to thank to Conselho Nacional de Desenvolvimento Científico e Tecnológico (CNPq) for the grants to IRBJ and OBFG; to Fundação de Amparo à Pesquisa do Estado de São Paulo (FAPESP) for the grants to CMHS and OBFG; and to anonymous reviewers.

\section{Conflicts of interest}

The authors declare that there are no conflicts of interest.

\section{References}

Aschliman NC, Claeson KM, McEachran JD (2012) Biology of sharks and their relatives. In: Carrier JC, Musick JA, Heithaus MR (eds). Phylogeny of Batoidea. Florida, EUA, pp 57-96. 
Carvalho MR (1999a). A systematic revision of the electric ray genus Narcine Henle, 1834 (Chondrichthyes: Torpediniformes: Narcinidae), and the higherlevel phylogenetic relationships of the orders of elasmobranch fishes (Chondrichthyes). Ph.D. thesis. The City University of New York.

Carvalho MR (1999b) A synopsis of the deep-sea genus Benthobatis Alcock, with a redescription of the type species Benthobatis moresbyi Alcock, 1898 (Chondrichthyes, Torpediniformes, Narcinidae). Society France Ichtbyology $231-255$

Carvalho MR, Compagno LJV, Ebert DA (2003) Benthobatis yangi, a new species of blind electric ray from Taiwan (Chondrichthyes, Torpediniformes, Narcinidae). Bulletin of Marine Science 72(3): 923-939

Claeson KM (2014) The impacts of comparative anatomy of electric ray (Batoidea, Torpediniformes) on their systematic hypotheses. Journal of Morphology 275: 597-612

Compagno LJV (1977) Phyletic Relationships of living sharks and rays. American Zoologist 17: 303-322

Heemstra PC, Smith MM (1980) Hexatrygonidae, a new family of stingrays (Myliobatiformes, Batoidea) from South Africa, with comments on the classification of Batoid fishes. Ichthyological Bulletin of the James Leonard Brierley Smith Institute of Ichthyology, 43:1-17

Hubbs CL, Ishiyama R (1968) Methods for the taxonomic study and description of skates (Rajidae). American Society of Ichtbyologists and Herpetologists 3:483-491

McEachran JD (1983) Results of the research cruises of FRV "Walther Herwig" to South America. LXI. Revision of the South American skate genus Psammobatis Günther, 1970 (Elasmobrancbii: Rajiformes, Rajidae). Arcbiv fïr Fischereinissenschaft 34(1): pp 23-80

McEachran JD, Dunn KA, Miyake T (1996) Interrelationships of Fishes. In: Stiassny MLJ, Parenti LR, Johnson GD (eds) Academic Press, San Diego, EUA, pp 63-83

McEachran JD, de Carvalho MR (2002) Batoid fishes. In: Carpenter KE (ed). FAO Species Identification Guide for Fishery Purposes, The Living Marine Resources of the Western Central Atlantic, 3rd ed. Rome: FAO. pp 508-589

McEachran JD, Aschliman N (2004) Biology of sharks and their relatives. In: Carrier JC, Musick JA, Heithaus MR (eds) Phylogeny of Batoidea. Florida, EUA, pp 79-114

Miyake T, McEachran JD (1991) The morphology and evolution of the ventral gill arch skeleton in batoid fishes (Chondrichtbyes: Batoidea). Zoological Journal of the Linnean Society 102:75-100
Nishida K (1990) Phylogeny of suborder Myliobatidoidei. Memoirs of the faculty of fisheries Hokekaido University 37(12): $1-108$

Rincón GF (1997) Taxonomia, alimentação e reprodução raia elétrica Benthobatis sp. (Torpediniformes: Narcinidae) no sul do Brasil. Pós-Graduação em Oceanografia Biológica. Fundação Universidade do Rio Grande

Rincón GF, Stehmann MFW, Vooren CM (2001) Results of the research cruises of FRV 'Walther Hewig' to South America. LXXIV. Benthobatis kereffi n. sp. (Chondrichtbyes, Torpediniformes, Narcinidae), a new deep-water electric ray from off South Brazil and the third species of the genus. Archive of Fishery and Marine Research 49(1): 45-60

Shirai S (1996) Interrelationships of Fishes. In: Carrier JC, Musick JA, Heithaus MR (eds) Phylogenetic Interrelationships of Neoselacbians (Chondrichthyes: Euselachii), Academic Press, San Diego, EUA, pp 09-34 


\section{Descripción Anatómica de Scapulocoracoid y Arcos Branquiales de Benthobatis kreffti}

Resumen.Esteestudiodescribela anatomía del escapulacoracoides de los arcos branquiales de Benthobatis kreffti, utilizando 10 muestras tomadas en $500 \mathrm{~m}$ de profundidad en la costa de São Paulo, Brasil. El escapulacoracoides tiene una fontanela anterior posicionada lateralmente. Los cóndilos presentan tamaño similar y no son equidistantes ni están alineados horizontalmente, en donde el mesocóndilo se sitúa debajo de los otros. Las fenestras posteriores se insertan en el cartílago, mientras las anteriores atraviesan el segmento lateral posterior del escapulacoracoides. La supraescápula está arqueada anteriormente, no se conecta o fusiona a la columna vertebral. En los arcos branquiales se encontraron tres elementos hipobranquiales no fusionados. Los ceratobranquiales tienen forma de bastón, con fenestras del primero al cuarto. El quinto morfológicamente diferente y conectado al escapulacoracoides. Se observó un par de elementos encima de la placa basibranquial cuyo origen se desconoce, y el cual ha sido reportado en otra especie del mismo género, Benthobatis marcida, siendo posible que dicho carácter constituya una autoapomorfia del género.

Palabras clave: anatomía; esqueleto; raya eléctrica; Torpediniformes; Chondrichthyes

\section{Descriçáo Anatômica do Escapulocoracóide e Arcos Branquiais de Benthobatis kreffti}

Resumo. Este estudo descreve a anatomia do escapulocoracóide e arcos branquiais de Benthobatis kreffti, com utilização de 10 exemplares coletados a $500 \mathrm{~m}$ de profundidade na costa de São Paulo, sudeste do Brasil. O escapulocoracóide possui fontanela anterior posicionada lateralmente. Os côndilos possuem tamanho semelhante, não são equidistantes nem estão alinhados horizontalmente, sendo o mesocôndilo situado abaixo dos demais. As fenestras posteriores se inserem na cartilagem, enquanto as anteriores atravessam o segmento latero-posterior do escapulocoracóide. A supraescápula é arqueada anteriormente e não conectada ou fusionada à sinarcual ou coluna vertebral. Nos arcos branquiais foram encontrados três elementos hipobranquiais não fusionados. Os ceratobranquiais possuem forma de bastão, com fenestras do primeiro ao quarto. O quinto é morfologicamente distinto e conectado ao escapulocoracóide. Há um par de elementos acima da cópula basibranquial cuja origem é desconhecida, também relatado para outra espécie do mesmo gênero, Benthobatis marcida, sendo possível que esse caráter constitua uma autapomorfia do gênero.

Palavras-chave: anatomia; esqueleto; raia-elétrica; Torpediniformes; Chondrichthyes 